\section{А.Г. Тепляков*}

Соблазн охранительства: историки, писатели и чекисты против критики большевистского террора

\author{
DOI: $10.31518 / 2618-9100-2019-1-1$
}

УДК 329.15:233.232."193”(093)

Выходные данные для цитирования:

Тепляков А.Г. Соблазн охранительства: историки, писатели и чекисты против критики большевистского террора // Исторический курьер. 2019. № 1 (3). Статья 1. URL:

http://istkurier.ru/data/2019/ISTKURIER-2019-1-01.pdf
A.G. Teplyakov*

\section{The temptation of guarding: historians, writers and security officers against criticism of the Bolshevik terror}

DOI: $10.31518 / 2618-9100-2019-1-1$

How to cite:

Teplyakov A.G. The temptation of preservation: historians, writers and security officers against criticism of the Bolshevik terror // Historical Courier, 2019, \# 1 (3). Article 1. [Available online:] http://istkurier.ru/data/2019/ISTKURIER-2019-1-01.pdf

Abstract: The article discusses the alarming trends that are noticeable in the modern historiography of Stalinist terror, which has been under great pressure from reactionary authors for the last ten years. For more than 25 years, domestic and foreign historians have been studying various aspects of terror on the basis of documents and generally agree with the view that terror was a universal method of government in the Stalin era, being an instrument of social engineering policy. However, the voices of those who believe that the construction of communism was a great goal are becoming louder and that terror does not matter much, since the number of victims of Bolshevism has been greatly exaggerated. The main material for the rehabilitation of Stalinist terror is supplied by historians of the FSB and the Home Office who defend the honor of the uniform, who are very poorly prepared in professional terms and cannot analyze the biased documents of the KGB department. Recently, their influence on civilian historians has increased, therefore, some researchers of Stalinism are refusing to criticize terror and fall into the apology of the Stalinist regime. These historians are captured by concepts that were created back in Stalin's time and justify terror. These researchers also demonstrate bias, misinterpretation of documents and dependence on the Soviet language. The author of the article believes that the professional historical community should oppose to falsifiers, both historians and publicists, objective statistics and competent interpretation of the causes and consequences of Stalin's terror.

Keywords: Stalin; terror; social engineering; departmental historiography; civilian historians; Soviet discourse; archaization.

The article has been received by the editor on 28.02.2019.

Full text of the article in Russian and references in English are available below.

Аннотация: В статье рассматриваются тревожные тенденции, заметные в современной историографии сталинского террора, которая последние десять лет испытывает большое давление со стороны авторов реакционного толка. Уже более 25 лет отечественные и зарубежные историки на основе документов изучают различные аспекты террора и в основном согласны с тем мнением, что террор был универсальным методом управления в сталинскую эпоху, являясь инструментом политики социальной инженерии. Однако все громче звучат голоса тех, кто считает, что строительство коммунизма было великой целью, а террор не имеет большого значения, поскольку численность жертв большевизма сильно преувеличена. Основной материал для реабилитации сталинского террора поставляют защищающие честь мундира историки ФСБ и МВД, очень плохо подготовленные в профессиональном плане и не умеющие

\footnotetext{
* Тепляков Алексей Георгиевич, канд. ист. наук, старший научный сотрудник, Институт истории Сибирского отделения Российской академии наук (Новосибирск, Россия), e-mail: teplyakov-alexey@rambler.ru

Teplyakov Alexey Georgievich, $\mathrm{PhD}$ in Historical Sciences, Senior researcher in Institute of History SB RAS, (Novosibirsk, Russia), e-mail: teplyakov-alexey@rambler.ru
} 
анализировать тенденциозные документы чекистского ведомства. В последнее время их влияние на гражданских историков возросло, поэтому часть исследователей сталинизма отказывается от критики террора и впадает в апологетику сталинского режима. Эти историки оказываются в плену концепций, которые созданы еще в сталинские времена и оправдывают террор. Данные исследователи также демонстрируют тенденциозность, превратное толкование документов и зависимость от советского языка. Автор статьи считает, что профессиональное историческое сообщество должно противопоставить фальсификаторам, как историкам, так и публицистам, объективную статистику и компетентное истолкование причин и последствий сталинского террора.

Ключевые слова: Сталин; террор; социальная инженерия; ведомственная историография; гражданские историки; советский дискурс; архаизация.

К настоящему времени большинство исследователей советской эпохи пришло к выводу, что именно террор, постоянный, с приливами и отливами, многофункциональный и беспощадный, не знавший государственных границ - был и остается олицетворением политики сталинского режима. Механизм террористического принуждения начали исследовать сразу после его первых проявлений в годы революции и Гражданской войны сначала противники большевизма в Советской России и белоэмигранты, затем внутрипартийные оппозиционеры и номенклатурные перебежчики, среди которых было много функционеров ВЧК-ОГПУ-НКВД-МГБ, а также западные политологи и историки. К сегодняшнему дню и отечественные, и зарубежные исследователи предложили ряд вариантов реконструкции механизма репрессий.

Современные историки отвергли идеи случайности и стихийности террора, доказали его решающую роль в социальных чистках, обратили внимание на соучастие общества в репрессиях, выделили бенефициаров карательной политики. Сегодня довольно хорошо изучены многочисленные категории репрессированных, включая представителей маргинальных групп населения, созданы научные биографии видных и рядовых жертв террора, включая самих чекистов, милиционеров, судей и прокуроров. Идет изучение влияния как пиков террора, так и террористической повседневности на общественную психологию и повседневную жизнь, на восприятие ее как элитами, так и «маленьким человеком». Достигнуты успехи в исследовании региональных аспектов террора, где особенно важна роль факторов, умножавших карательный эффект сталинских чисток (наличие государственной границы, крупной промышленности, оборонных заводов и воинских частей, значительное число бывших участников антикоммунистических восстаний, присутствие политической и крестьянской ссылки и пр.). Изучается субъективный фактор в лице карьеристов из числа руководителей ВЧК-ОГПУ-НКВД, роль различных структурных подразделений аппарата НКВД, взаимодействие органов госбезопасности с партийным аппаратом, судом и прокуратурой, роль вспомогательных чекистских подразделений, активно способствовавших проведению террора, особенно в периоды обострения карательной политики.

Историки экономики установили, что именно в 1937 г. в СССР начался серьезный экономический кризис и спад промышленного производства. Одной из его причин стали массовые аресты инженерно-технических работников, падение качества руководства и трудовой дисциплины. Серьезный кризис в 1937-1938 гг. охватил и гулаговский сектор советской экономики, в который влилось порядка миллиона заключенных. Оказалось, что лагерная система не смогла «освоить» огромные потоки арестантов, что привело к дезорганизации работы и массовой смертности узников. По справедливому мнению О. В. Хлевнюка, проблема последствий террора имеет всеобъемлющий характер, потому что не существовало ни одной области социально-экономической жизни, которую не затронули 
бы массовые аресты и расстрелы ${ }^{1}$. Дальнейшее изучение этих вопросов - одна из перспективных задач для историков советского общества.

Разнообразные аспекты сталинского террора активно изучаются уже более четверти века. Однако в последние годы все отчетливее слышны голоса тех, кто считает критику сталинского режима антипатриотичной и крайне вредной с точки зрения государственных интересов. Обществу внушается мысль, что у великой России всегда были могущественные враги, справиться с которыми можно лишь с помощью мобилизационной политики и могучих органов государственной безопасности. При анализе советского опыта научный концепт модернизации фактически подменяется голой технологической революцией, в которой, по мнению апологетов сталинского «великого перелома», вполне логично уживаются такие «издержки», как феодальная эксплуатация крестьян, рабочих и интеллигенции, а также по сути рабовладельческий сектор ГУЛАГа. Варварская растрата человеческого капитала, который уничтожался и подрывался голодом, нищетой и репрессиями, считается неизбежной ценой стремительного и спасительного для судеб страны модернизационного индустриального процесса, который просто не мог протекать иначе.

Современная власть с целью наиболее полноценной, с ее точки зрения, легитимации ориентируется на преемственность со всеми историческими эпохами, поэтому под лозунгом общественной стабильности провозглашает положительную оценку как имперского, так и советского прошлого. В последние годы вмешательство государства в политику исторической памяти усиливается, что прямо связано с жестким идеологическим противостоянием Западу. Правда, следует учитывать, что политическая, экономическая и культурная элита России по-прежнему ориентируется на Запад, что делает пропагандистские заявления о противостоянии с «традиционным врагом-русофобом» обычными симулякрами, призванными мобилизовать население и сплотить его вокруг власти. Впрочем, это типично и для остального современного мира, активно запускающего в обиход именно такие ложные пропагандистские конструкции на злобу дня. Однако российская власть, в отличие от властей развитых демократических государств, серьезно влияет на возможности исследователей, ограничивая доступ к архивным документам и пропагандируя самые архаические воззрения на события прошлого. В результате возможность общественного обсуждения актуальных вопросов советской эпохи затрудняется, что искажает и без того противоречивую самоидентификацию россиян.

Новейшая историографическая волна помутнела и в ней пытаются ловить рыбу носители откровенно сталинистских и ксенофобских взглядов, считающие, что строительство социализма было великим делом, которое подвергнуто неоправданному поношению. Тема большевистского террора для таких исследователей является наиболее раздражающей. Они не скрывают, что во имя интересов государства историческая правда должна помалкивать. Им нравится закавычивать такие термины, как, например, «репрессии» или «реабилитация». Наиболее реакционные позиции занимают выходцы из структур госбезопасности и МВД, нередко обладающие монопольным правом на ознакомление с делопроизводством «органов». Самым плодовитым автором среди выходцев из ФСБ является О.Б. Мозохин, который сначала получил известность благодаря участию в поиске захоронений жертв террора, а затем перешел на службу в Архив Президента РФ, где долгое время фактически монопольно распоряжался его фондами и выпускал на основе ценнейших архивных источников свои документальные поделки. К сожалению, он не в состоянии грамотно анализировать и удовлетворительно комментировать документы, вводимые им в научный оборот. Мозохин покорно следует за тенденциозными чекистскими источниками, принимает на веру их объяснения и допускает, в силу некомпетентности, детские ошибки. Устаревшие взгляды Мозохина и небрежность в работе с источниками сильно сказались в его самой

\footnotetext{
${ }^{1}$ Хлевнюк О.В. Сталинский период советской истории. Историографические тенденции и нерешенные проблемы // Уральский исторический вестник. 2017. № 3. С. 74.
} 
известной книге ${ }^{2}$, где он открыто заявляет, что у органов госбезопасности было законные права на широкие репрессии, «делегированные им высшими законодательными органами государства». Защита чекистов - его принцип. Например, Мозохин сообщает, что циркуляр прокуратуры СССР от 20 июня 1934 г. о процедуре привлечения к уголовной ответственности сотрудников ОГПУ, вызвал протест руководства «органов», поскольку в циркуляре содержалась ссылка на возрастание случаев должностных преступлений чекистов, связанных с превышениями власти и издевательствами над арестованными, вплоть до их убийств. Такая оценка показалась сталинским чекистам незаслуженной. Характерно, что Мозохин, слепо веря чекистским оценкам, фактически солидаризировался с мнением ОГПУ о необоснованности прокурорских выводов об увеличении числа тяжких преступлений среди сотрудников «органов» ${ }^{3}$.

В последних своих работах Мозохин нападает уже на сам процесс реабилитации, одновременно восхваляя дело строительства социализма: «Тема репрессий в СССР сильно и незаслуженно раздута. Ни в одной стране мира эти темы так обстоятельно не обсуждаются, хотя жертв беззаконий там было не меньше. [...] Горбачевский указ 1989 г. и ельцинский закон 1991 г. о реабилитации жертв политических репрессий привели к тому, что сотрудники государственной безопасности совместно с Прокуратурой стали “скопом реабилитировать" как невинно пострадавших, так и преступников. [...] В настоящий момент уже невозможно разобраться, кто реабилитирован справедливо, а кто нет». Публикация документов о репрессиях, по Мозохину, «преследовала целью дискредитацию идей социализма, создание негативного имиджа России» ${ }^{4}$.

Отставной генерал-лейтенант ФСБ и плодовитый автор А.А. Зданович публично заявил о своей уверенности в существовании «заговора военных» во главе с М.Н. Тухачевским, выразив удовлетворение, что «органы госбезопасности вовремя пресекли эту попытку, которая могла вылиться во что-то кровавое» 5 . В своих книгах Зданович пытается, не приводя какой-то конкретики, усомниться, например, в лояльности чекистов-поляков, которые с начала 1920-х годов подвизались в ВЧК-НКВД, внесли большой вклад в карательную политику и были репрессированы в ходе Большого террора, а также упоминает, что в 1938 г. в ряде регионов СССР действовало диверсионное подполье, направляемое странами Запада ${ }^{6}$. Подобного рода оценки, часто выраженные в форме намеков, а где-то и вполне откровенно, говорят скорее об опыте дезинформационных акций, нежели о профессионализме Здановича как исследователя.

Недовольный тем, что международные проекты, организованные немецким историком

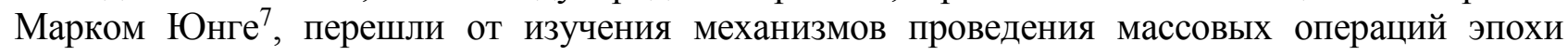
Большого террора к малоизученной и еще более неприятной для имиджа ФСБ теме организации судебных процессов в 1939-1941 гг. над «перестаравшимися» сотрудниками советских органов государственной безопасности, Зданович увлеченно предался конспирологическим «объяснениям», обвинив автора данной статьи в постепенном

2 Мозохин О.Б. Право на репрессии: Внесудебные полномочия органов государственной безопасности (1918-1953). Жуковский; М.: Кучково поле, 2006. 480 с.

${ }^{3}$ Там же. С. 204.

${ }^{4}$ Мозохин О.Б. Статистические сведения о деятельности органов ВЧК-ОГПУ-НКВД-МГБ (1918-1953 гг.). М.: Алгоритм, 2016. С. 330-331.

${ }^{5}$ Гришин А. Заговор Тухачевского существовал // Комсомольская правда. 2017. 29 мая.

6 Зданович A.A. Польский крест советской контрразведки. Польская линия в работе ВЧК-НКВД. $1918-1938$. М.: Крафт+, 2017. С. 146, 152, 396-400.

7 Юнге М., Бордюгов Г., Биннер Р. Вертикаль Большого террора. История операции по приказу НКВД № 00447. М.: Новый хронограф, АИРО-ХХІ, 2008. 784 с.; Сталинизм в советской провинции: 1937-1938 гг. Массовая операция на основе приказа № 00447 / под ред. М. Юнге, Б. Бонвеча, Р. Биннера. М.: РОССПЭН, 2009. 927 с.; Массовые репрессии в Алтайском крае 1937-1938 гг. Приказ № 00447 / сост. Г. Д. Жданова, В.Н. Разгон, М. Юнге, Р. Биннер и др. М.: РОССПЭН, 2010. 751 с.; «Через трупы врага на благо народа». «Кулацкая операция» в Украинской ССР: 1937-1941 гг.: в 2 т. М.: РОССПЭН, 2010. 743, 711 с.; Юнге М., Бонвеч Б. Большевистский порядок в Грузии: в 2-х т. М.: АИРО-XXI, 2015. 640, 656 с. 
расширении исследовательской тематики интернациональной группы историков в сторону изучения темы наказаний сталинских карателей и их «дисциплинирования» при Л.П. Берии 8 Конечно, нам было бы приятно считать себя «мозгом» большого исследовательского проекта, завершившегося публикацией в общей сложности пяти книг в серии «Эхо Большого террора» (2017-2019 гг.) ${ }^{9}$, однако душой и мотором нашего предприятия был и остается М. Юнге. Все эти выпады могли бы показаться забавными, если бы не отчетливый привкус политических обвинений, привычных для доказательной методики экс-генерала ФСБ, не очень уверенно, несмотря на обилие напечатанного, чувствующего себя на историческом поле.

Откровенно просталинским образом высказывается целый ряд других авторов - выходцев из спецслужб. Так, о крупном сталинском чекисте Б.А. Баке пишется так: «Около десятка лет в Самаре он разоблачал вредителей, кулаков-террористов, замышлявших или совершивших свои злодеяния» ${ }^{10}$. К.В. Скоркин одобрительно высказывается об идее создания трудовых армий Л.Д. Троцкого, именуя ее «блестящей», о раскрестьянивании («руководство СССР к весне 1932 г. добилось коренного перелома в политике коллективизации, завершило раскулачивание и высылку всех антисоветски настроенных элементов») и паспортной системе, позволившей «существенно разгрузить города от избыточного населения и удалить из них антисоветски настроенный элемент» ${ }^{11}$.

Признать большевистский террор необходимым и по возможности оправдать сотрудников карательных органов - очевидная тенденция ведомственной историографии деятельности ОГПУ-НКВД, влияющая в последние годы и на гражданских историков, причем с каждым годом все сильнее. Так, в журнале «ФСБ: за и против» ${ }^{12}$ в 2013 г. появилась хвалебная статья А. Терещенко о видном чекисте-генерале Н.Г. Кравченко, который начал свой стремительный карьерный рост в 1938 г. в органах НКВД Украины за счет активной деятельности, направленной на проведение пресловутых «национальных операций». Автор скорбит о крахе карьеры Кравченко, который в 1959 г., будучи начальником Особого отдела Прикарпатского военного округа, оказался уволен из КГБ и лишен как генеральского звания, так и половины пенсии. По мнению автора, этот способный и честный чекист стал жертвой усердия военного прокурора, который де «сфабриковал» дело о ложности подготовленных Кравченко уголовных дел на польских «шпионов», поскольку агенты Польской организации войсковой (ПОВ) якобы действовали в начале 1930 -х годов на всей(!) территории СССР ${ }^{13}$. Отметим, что мифическое мнение о масштабах деятельности ПОВ в СССР 30-х годов может опираться на публикации упомянутого выше А.А. Здановича.

Сегодня у ведомственных историков-«охранителей» появилась открытая поддержка свыше. Директор ФСБ А. Бортников в интервью, данном в декабре 2017 г. по случаю векового юбилея ведомства, заявил, что значительная часть следственных материалов 1930-х годов была обоснована, а те, кто выступал против Сталина, являлись действительными

\footnotetext{
8 Зданович A.A. К вопросу изучения истории ВЧК-НКВД на современном этапе: полемические заметки // Клио (СПб.). № 3 (135). 2018. С. 196-205.

9 Чекисты на скамье подсудимых: сб. ст. / сост. М. Юнге, Л. Виола, Дж. Россман. М.: Пробел-2000, 2017. 680 с.; Эхо Большого террора. Сборник документов в трех томах. Под ред. Л. Виолы, Дж. Россмана, М. Юнге. Т. 1: Партийные собрания и оперативные совещания сотрудников Управлений НКВД УССР (ноябрь $1938-$ ноябрь 1939 гг.). / сост.: В. Васильев, Л. Виола, Р. Подкур. М.: Пробел-2000, 2017. 736 с.; Т. 2: Документы из архивных уголовных дел сотрудников органов УНКВД Украины, осужденных за нарушения социалистической законности (октябрь 1938 г. - июль 1943). Кн. 1: НКВД Молдавской АССР, Дорожно-транспортный отдел ГУГБ НКВД Северо-Донецкой железной дороги, УНКВД по Житомирской и УНКВД по Одесской области. / Сост.: С. Кокин, Дж. Россман. М.: Пробел-2000, 2017. 720 с.; Т. 3: Чекисты Сталина в тисках «социалистической законности». Эго-документы 1938-1941 гг. / сост.: А. Савин, А. Тепляков, М. Юнге. М.: Пробел-2000, 2018. 928 с. Публикация второй книги второго тома ожидается в 2019 г.

${ }^{10}$ Громов А.В., Хорошавин В.А., Хумарьян С.Г. Самарский щит: Очерки, посвященные 90-летию Управления ФСБ по Самарской области. Самара, 2008. С. 83.

${ }^{11}$ Скоркин К.В. Обречены проиграть. Власть и оппозиция, 1922-1934. М.: ВивидАрт, 2011. С. 854, $500,766$.

12 Просмотрев подшивку этого журнала за последние годы, мы не обнаружили там, вопреки названию, никаких материалов «против» репутации ведомства.

${ }^{13}$ Терещзенко А. Судьба генерала // ФСБ: За и против. 2013. № 2. С. 33.
} 
врагами государства и шпионами иностранных разведок: «Архивные материалы свидетельствуют о наличии объективной стороны в значительной части уголовных дел, в том числе легших в основу известных открытых процессов [1930-х годов]» ${ }^{14}$.

В последние годы особенно заметно, что чекистская точка зрения стала выглядеть привлекательной и для тех историков, которые заслуженно имели приличную академическую репутацию. Для них характерно полное абстрагирование от трагедий прошлого. В коллизиях репрессивной политики они видят только целесообразность или нецелесообразность, и ничего более (характерно, что и авторы советских документов, рассказывающих о преступлениях чекистов, совершенно равнодушны к жертвам сталинских карателей, беспокоясь обычно только о неизбежной дискредитации власти). Все остальное объявляется несущественным.

Ряд историков демонстрирует настоящий страх перед подлинными документами, выявление которых объявляется антигосударственным делом. Так, Б.А. Старков прямо обвинил критиков сталинщины в антипатриотизме и выступил против «стихийного рассекречивания» документов, заявив: «Трактовка деятельности органов государственной безопасности в истории российской государственности приобрела негативный, антинародный и антинациональный характер» ${ }^{15}$. Ссылаясь на печально памятного председателя КГБ СССР В.А. Крючкова, уничтожившего в начале 1990-х годов огромное количество важнейших документов своего ведомства, Г.А. Куренков оправдывает современную закрытость российских архивов, соглашаясь с тезисом Крючкова о том, что «неосторожное обращение с архивами может нанести непоправимый ущерб» государству ${ }^{16}$.

Сталинский дискурс по-прежнему довлеет над многими исследователями. Идейные и лексические конструкции ленинско-сталинской эпохи до сих пор считаются вполне адекватными для описания исторической реальности. Ряд известных специалистоваграрников давно заменяют идеологически определенный термин «раскулачивание» на «раскрестьянивание» (С.А. Красильников ${ }^{17}$ ) или «репрессивное раскрестьянивание» (В.А. Ильиных), однако многие историки по сей день считают возможным употреблять данный термин без кавычек, сопротивляясь его изъятию из научного языка. Полагаем, что современная историческая наука должна начинать процесс отторжения и такого ключевого понятия сталинской эпохи, как «коллективизация». Под этим привычным и носящим вполне положительные коннотации термином на деле скрываются катастрофические для народного хозяйства и общества в целом силовые процессы принудительного огосударствления аграрного сектора, что привело к полному уничтожению жизненного уклада основной части населения страны. Часто используемый вариант «насильственная коллективизация» в целом является менее точным, чем «репрессивное раскрестьянивание». С нашей точки зрения, процесс силового огосударствления сельского хозяйства правильнее было бы описывать как принудительно-репрессивные акции в системе становления и утверждения мобилизационной экономики.

В новейшей книге В.В. Кондрашина и О.Б. Мозохина о политотделах МТС 1930-х годов на основе чекистских документов показана деятельность этих своеобразных властных органов на местах, представлявших собой гибрид мини-райкомов с райотделами ОГПУ. Авторы критикуют устоявшееся в литературе мнение о преимущественно террористическом направлении деятельности политотделов МТС, беря на веру подготовленные чекистамиполитотдельцами информационные сводки, в которых содержится огромное количество сведений о «вредительской» и «саботажнической» деятельности колхозников. Авторы солидаризируются с чекистским мнением в том, что политотделы МТС преследовали

\footnotetext{
${ }^{14}$ ФСБ расставляет акценты // Российская газета. 2017. 20 дек. С. 4.

15 Старков Б.А. «План Д»: вымыслы и действительность // Исторические чтения на Лубянке. 2005 год. М.: Кучково поле, 2006. С. 15-16.

${ }^{16}$ Куренков Г.А. От конспирации к секретности: Защита партийно-государственной тайны в РКП(б)-ВКП(б), 1918-1941 гг. М.: АИРО-ХХІ, 2015. С. 221.

${ }^{17}$ См. Красильников С.А. Серп и Молох. М.: РОССПЭН, 2003, 2009.
} 
настоящих вредителей, которые и были виновниками плохой работы колхозов и совхозов (неумелым и плохо мотивированным механизаторам, нещадно ломавшим технику, приписаны, таким образом, сознательные саботаж и вредительство!). С точки зрения Кондрашина и Мозохина, государственные репрессии в этом случае не помешали, а помогли экономике. Чутко улавливая конъюнктуру, авторы доказывают созидательность работы политотделов, выявлявших истинных врагов социализма, по наведению порядка в деревне, а также связывают «успехи» сталинской модернизации с проблемой экономических санкций западных стран против современной России и поставленной президентом В.В. Путиным задачей широкого импортозамещения ${ }^{18}$.

Что касается такого известного статистика репрессий, как В.Н. Земсков, то для него характерно сильное упрощенчество в толковании тех документов, которые он видел (и далеко не исчерпывающих тему). Крайняя жестокость тюремно-лагерного и ссыльного режима им просто опускается, поскольку эти элементы репрессивного механизма слабо описываются статистикой. При этом автор путается в категориях репрессированных, отождествляя ссыльных периода «чистки» городов от «социально-вредных элементов» в 1933 г. с «кулаками». Он открыто провозглашает своей целью защиту Сталина от дискредитации со стороны идейно-политических противников СССР и заявляет, что 97,5 \% населения при Сталине не подвергались репрессиям ни в какой форме ${ }^{19}$. У Земскова жертвы - это только умершие. «Актированные» узники ГУЛАГа (сотни тысяч!), в основном умершие за колючей проволокой, но формально уже свободные, все те, кто подорвал здоровье в застенках, покончил с собой или сошел с ума от ужаса перед арестом, - это не «настоящие» жертвы. С точки зрения Земскова, раз статистика относительно данных категорий пострадавших от действий режима ему недоступна (между тем сведения о гигантских масштабах «актированных» по инвалидности имеются в документах санитарного отдела ГУЛАГа и были обнаружены псковским историком М.Ю. Наконечным) или просто отсутствует, то даже говорить об этом не стоит. Земсков обвиняет А. И. Солженицына в огромном преувеличении жертв большевизма ${ }^{20}$, игнорируя тот факт, что писатель на деле говорил не только об убитых и умерших в заключении, но и фиксировал внимание на многомиллионных потерях из-за дефицита рождаемости и общем колоссальном сокращении населения как результате демографической катастрофы в России первой половины XX века.

Историки, идеализирующие сталинизм и чекистов, не в силах предложить какие-либо оригинальные и обоснованные идеи, питаясь исключительно реликтами далекого прошлого. Для части из них сохраняют актуальность даже объяснения хрущевской поры, вроде такого: «Грубость и болезненная подозрительность [Сталина] оказались на руку иностранным разведкам, а также карьеристам, авантюристам, враждебным элементам, пробравшимся в советские органы безопасности и начавшим в массовом порядке фабриковать одно за другим дела об измене и предательстве руководящих работников партии» ${ }^{21}$. В скандально известном учебнике А.С. Барсенкова и А.И. Вдовина 22 раздел, в котором говорится о сталинском терроре и его жертвах, озаглавлен в точном соответствии с чекистской оценкой 30-х годов: «Удары по потенциалу “пятой колонны”». В свою очередь В.И. Бакулин решительно заявляет, что для него остается «открытым вопрос об истинном содержании и историческом месте публичных политических процессов 1930-х гг.»; также он отвергает мнение о том, что подавляющее большинство репрессированных в 1937-1938 гг. «являлись "невинными жертвами тоталитарного режима" ${ }^{23}$.

\footnotetext{
${ }^{18}$ Кондрашин В.В., Мозохин О.Б. Политотделы МТС в 1933-1934 гг. М.: Русская книга, 2017. 304 с.

19 Земсков В.Н. Сталин и народ. Почему не было восстания. М.: Алгоритм, 2014. С. 103.

20 Там же. С. 95, 12.

${ }^{21}$ Верховцев И. Ленинские нормы партийной жизни. М.: Госполитиздат, 1962. С. 29.

${ }^{22}$ Барсенков А.С., Вдовин А.И. История России. 1917-2009: учеб. пособие для вузов. 3-е изд. М.: Аспект Пресс, 2010. 846 c.

23 Бакулин В.И. Кадровые «чистки» 1933-1938 гг. в Кировской области и проблемы консолидации советского общества // Отечественная история. 2006. № 1. С. 148-153.
} 
Некоторые историки, пишущие о терроре, прямо скатываются к защите открытых судебных процессов сталинской эпохи, реанимируя самые мрачные историографические призраки. Так, известный альманах «Русский сборник. Исследования по истории России», т. XXV, вышедший в 2018 г. и составленный О. Р. Айрапетовым, М. А. Колеровым, Б. Меннингом, А.Ю. Полуновым и П. Чейсти, целиком посвящен теме событий 1937 года и резко делится на две неравные части. Помимо вполне профессиональных статей таких заметных исследователей, как А.В. Ганин, О.Л. Лейбович, М.В. Соколов и др., в 544страничном альманахе помещен 150-страничный блок из четырех архаичных и малосодержательных, но объемистых публикаций, преимущественно маргинальных авторов, наглядно демонстрирующий интеллектуальную немощь современных «охранителей».

Это хорошо видно в большой статье В. Э. Багдасаряна «Тридцать седьмой - через призму историографического моделирования». Багдасарян еще в 2007 г. выделил основные, по его представлению, модели историографического дискурса по проблеме 1937 г., среди которых уже изрядно устаревшие ко времени публикации статьи «самоистребление революционеров», «сталинский термидор», «патологическая личность», «еврейский заговор» и др..$^{24}$, хотя на 2007 г. все эти концепции не разделялись основными интерпретаторами темы. После рассекречивания советских архивов уже почти не осталось сторонников идеи о том, что 1937 г. был сосредоточен на истреблении элиты. Также лишь маловлиятельное меньшинство историков продолжает настаивать на том, что Большой террор был слепым и безадресным, воплощая конфликты либо между слабой сталинской властью и сопротивлявшимися ей региональными элитами, либо имея основой попустительство властей желанию широких масс посчитаться со всеми, кто «мешал народу». Основная часть исследователей доказала тот факт, что Большой террор являлся подготовленной и целенаправленной акцией, решавшей в огромной степени задачи социальной инженерии ${ }^{25}$. Между тем Багдасарян совершенно игнорирует ключевую для понимания террора проблему социальных чисток с целью физического избавления социума от нежелательных элементов, критикуя «сентиментализм западной историографии в отношении жертв сталинских репрессий». Спустя десятилетие, в 2018 г., он в нарушение научной этики публикует в «Русском сборнике» под слегка измененным названием этот же вариант своей работы - со всеми прежними оценками, потерявшими актуальность примерно двадцать лет назад. При этом Багдасарян даже не упоминает основополагающую по теме «тридцать седьмого» монографию М. Юнге и Р. Биннера «Как террор стал “Большим”». Зато, как и в 2007 г., он заканчивает статью выводом, отражающим некомпетентность автора и не дающим четкого ответа, что же он имел в виду, когда писал об «идеологических табу» относительно причин террора второй половины 1930-х годов: «Несмотря на декларируемый историографический плюрализм, тематика "Большого террора" остается очерченной рамками идеологического табу. Ряд реконструированных объяснительных моделей тридцать седьмого года попросту не допущен в поле академической науки» ${ }^{26}$.

Не более вразумительными являются и остальные материалы этого блока «Русского сборника». Прилегающие к работе Багдасаряна три статьи (В.Л. Бобров. Смерть Орджоникидзе: вопросы историографии. С. 378-428; Гровер Ферр. В оппозиции к Сталину: малоизвестный Лев Седов, сын Льва Троцкого. С. 429-439; Свен-Эрик Хольмстрем. Крупицы правды среди нагромождений лжи: «полет Пятакова в Осло» в свете фактов. С. 440-495) продвигают те самые объяснительные модели, которые отвергаются

\footnotetext{
${ }^{24}$ Багдасарян В. Э. «Загадочный тридцать седьмой». Опыт историографического моделирования // Историография сталинизма / под ред. Н.А. Симония. М.: РОССПЭН, 2007. С. 172-206.

${ }^{25}$ Хлевнюк О. В. 1937-й: Сталин, НКВД и советское общество. М.: Республика, 1992. 270 с.; Юнге М., Биннер Р. Как террор стал «Большим». Секретный приказ № 00447 и технология его исполнения. М., АИРОXXI, 2003. $352 \mathrm{c}$.

${ }^{26}$ Багдасарян B.Э. Тридцать седьмой - через призму историографического моделирования // Русский сборник. Исследования по истории России». Т. XXV / ред.-сост. О.Р. Айрапетов, М.А. Колеров, Б. Меннинг, А.Ю. Полунов, П. Чейсти. М.: Модест Колеров. 2018. С. 377.
} 
академической наукой, а именно разнообразные экзотические концепты на основе доверия к советским источникам, особенно материалам «московских процессов» 30-х годов. В.Л. Бобров настолько пристрастен в своем желании опровергнуть факт самоубийства Г.К. Орджоникидзе, что даже берет в кавычки раздражающий его термин «реабилитация». Американский литературовед Г. Ферр, выступающий с предельно ортодоксальносталинистских позиций, уверяет, что маршал Тухачевский и его подельники по процессу 1937 г. о «военно-фашистском заговоре в РККА» имели криминальные связи как с Л.Д. Троцким, так и германской и японской разведками (с. 438). Особенно анекдотически выглядят любительские попытки Хольмстрема собрать доказательства тайного перелета Г.Л. Пятакова в 1935 г. из Германии в Норвегию для встречи с Троцким, с одновременным заявлением о причастности к «заговору троцкистов» и тогдашнего главы НКВД Г.Г. Ягоды. Остается только удивляться альманаху, решившему представить профессиональному читателю столь тенденциозно и архаично выглядящий раздел, просто уничтожающий репутацию «Русского сборника».

Налицо и попытки фальсификации источников по истории террора. Недавно А.Н. Дугин крайне беспомощно попытался подвергнуть сомнению подлинность знаменитой шифротелеграммы Сталина о разрешении пыток в отношении «врагов народа», не приведя никаких серьезных доводов и тем самым показав поверхностное отношение академических «Вопросов истории» к экспертизе публикаций ${ }^{27}$. В попытках отвергнуть масштабы и жестокость террора он идет на откровенные подтасовки. Например, не имея каких-либо заметных научных заслуг, Дугин называет псевдоисториками Р. Медведева, Р. Конквеста и Д. Волкогонова. Также он подвергает сомнению опубликованные от имени Правительства РФ основные документы об уничтожении польских военнопленных в 1940 г.: записку Л.П. Берии от 29 марта 1940 г. о расстреле пленных поляков и соответствующее решение Политбюро ЦК ВКП(б) от 5 марта 1940 г. Еще Дугин повторяет конспирологическую версию публицистов-сталинистов Ю. Мухина и Е. Прудниковой об убийстве Сталина и Берии, а также заявляет, что Н.С. Хрущев якобы распорядился создать специальную группу из 200 сотрудников КГБ для изъятия и подделки архивных документов ${ }^{28}$.

Дугин пытается реабилитировать Сталина во всем: «Многие современные историки, обвиняя Сталина во всех смертных грехах, приписывают ему бесчеловечную идею ускоренной индустриализации за счет нещадной эксплуатации крестьян, изъятию у них даже семенного зерна, что и привело к “многомиллионным" жертвам голода в начале 30-х годов. Данная версия - не более чем выдумка некомпетентных публицистов или историков». Далее автор просто нагнетает истерику: «Представим на секунду, что некий компетентный орган признает Сталина преступником, что Советское государство будет признано не одним из победителей в войне с фашизмом, а соучастником развязывания Второй Мировой войны. [...] Наши заклятые большие и малые стратегические “партнеры” только и ждут подобного правового повода, чтобы предъявить территориальные претензии и триллионные иски нашей стране, искромсав тем самым Российскую Федерацию на большие и малые кусочки» ${ }^{29}$. Кстати, подобным низкопробным пафосом отличалась недавняя попытка реакционных церковных кругов возродить интерес к давно отставленной теме якобы «ритуального убийства царской семьи» в июле 1918 г.

В попытках реабилитировать террор отметились в том числе некоторые специалисты по истории литературы, выпустившие под эгидой известного филолога сборник статей об «Архипелаге ГУЛАГ», озаглавленный «Книга, обманувшая мир», призванный уничтожить репутацию А. И. Солженицына как писателя, историка и патриота ${ }^{30}$. Аннотация к этой книге,

27 Дугин А.Н. Шифротелеграмма И.В. Сталина от 10 января 1939 года (источниковедческий анализ) // Вопросы истории. 2017. № 1. С. 97-112.

${ }_{28}^{28}$ Дугин А.Н. Антисталинская подлость // Российские вести. 2013. 10-16 мая. № 12 (2119).

29 Там же.

30 Книга, обманувшая мир: сб. критических статей и материалов об «Архипелаге ГУЛАГ» А.И. Солженицына / сост. и ред. В.В. Есипов. М.: Летний сад, 2018. 520 с. 
составители которой не побрезговали хамскими выпадами известного своей вульгарностью сталиниста В. Бушина и допустили откровенно жульнические нападки на историю создания «Архипелага», в котором на самом деле было использовано более 200 мемуарных текстов, присланных Солженицыну узниками ГУЛАГа, провозглашает: «В сборнике представлены статьи и материалы, убедительно доказывающие, что “главная" книга Солженицына, признанная “самым влиятельным текстом" своего времени, на самом деле содержит огромное количество грубейших концептуальных и фактологических натяжек, способствовавших созданию крайне негативного образа нашей страны. Сборник показывает давнюю традицию неприятия “Архипелага ГУЛАГ” в истории общественной и литературной мысли России, анализирует причины широкого внедрения этой книги в массовое сознание и раскрывает глубокую пагубность ее влияния на политические процессы в мире и в нашей стране. Пресловутые “шестьдесят миллионов” Солженицына оказались, к несчастью, крайне живучими и сыграли далеко не безобидную, а, наоборот, роковую роль в истории. Их можно сравнить со своеобразными каббалистическими знаками или с “черной магией”, заворожившей едва ли не все мировое общественное сознание».

По сути, в «Книге, обманувшей мир» фиксируется признание значения труда Солженицына как способного перевернуть сознание мыслящего слоя целой страны. Именно колоссальные цифры потерь от террора и голода, потрясшие читателей «Архипелага», вызывают возмущение тех современных публицистов, которые считают себя главными патриотами Отечества. Но современные данные о демографических потерях СССР не отличаются принципиальным образом от солженицынских. В результате голода и болезней, вызванных в том числе политикой большевиков, погибла огромная часть населения России: до 10 млн в Гражданскую войну, примерно шесть миллионов в период голодовок 19211923 гг., семь миллионов в 1932-1933 гг., примерно такое же количество в 1941-1945 гг., до двух миллионов в 1945-1953 гг. Далее идут три с лишним миллиона умерших в местах заключения (к официальной смертности в ГУЛАГе с 1930 г. - 1,8 млн - нужно прибавить более полумиллиона умиравших «актированных», сотни тысяч умерших в тюрьмах начала 20-х и местах заключения наркомата юстиции в начале 30-х годов, а также 600 тыс. умерших в «кулацкой» ссылке и сотни тысяч - в национальной ссылке) и более миллиона расстрелянных. Еще сотни тысяч - это покончившие с собой из страха репрессий и отчаяния после ареста близких, а также преждевременно умершие от колоссальных стрессов. Это в сумме дает до 40 миллионов человек, ставших прямыми жертвами ленинско-сталинской политики. Причем на Гитлера все потери в войне никак не списать - в них также виноваты те, кто с 1932 г. основную часть бюджета страны направлял на оборону, но так и не смог достойно подготовить СССР к войне с национал-социалистами. Понимание того, что вместе с прямыми и косвенными потерями страна не досчиталась в XX веке до 100 миллионов граждан - вполне достаточная причина, чтобы отказать в доверии коммунистам и согласиться с приоритетом общечеловеческих ценностей, переходом к рынку и демократии. Этот тезис по-прежнему вызывает у многих сторонников большевизма откровенную ярость и настоящую войну со здравым смыслом.

В последнее время в России налицо тревожные процессы атомизации социума и деградации гражданского общества, торжества автаркии и обскурантизма. В условиях архаизации общественных институтов все более заметно появление в исторической науке сочинений, которые находятся в русле реакционных представлений, опровергая накопленные исследователями объективные знания о советском прошлом. Данный обзор некоторых работ последнего десятилетия призван продемонстрировать настоящий прорыв в академическую среду отжившей исторической лжи, что является отражением как усиления позиций ведомственных историков, занимающихся лакировкой истории спецслужб, огромным валом вульгарно-сталинистской публицистики, а также опасным симптомом деградации целого ряда гражданских исследователей, испытывающих непреодолимое желание проникнуться духом «чекизма». Профессиональные историки, публикующие свои работы в соавторстве с ведомственными, принимают точку зрения последних и откровенно 
деградируют. Возрождаются и культивируются советский язык, подходы времен холодной войны и методы очернения идейного противника с предъявлением политических обвинений. Архаизации научного дискурса следует противопоставить подлинные ценности академической науки, несущие гуманистический потенциал и отрицающие новые линии общественного размежевания.

\section{Литература}

Багдасарян B.Э. «Загадочный тридцать седьмой». Опыт историографического моделирования // Историография сталинизма / под ред. Н.А. Симония. М.: РОССПЭН, 2007. C. 172-206.

Багдасарян В.Э. Тридцать седьмой - через призму историографического моделирования // Русский сборник. Исследования по истории России». Т. XXV / ред.-сост. О.Р. Айрапетов, М.А. Колеров, Б. Меннинг, А.Ю. Полунов, П. Чейсти. М.: Модест Колеров. 2018. С. 344-377.

Бакулин В.И. Кадровые «чистки» 1933-1938 гг. в Кировской области и проблемы консолидации советского общества // Отечественная история. 2006. № 1. С. 148-153.

Барсенков А.С., Вдовин А.И. История России. 1917-2009: учеб. пособие для вузов. 3-е изд. М.: Аспект Пресс, 2010. 846 с.

Верховцев И. Ленинские нормы партийной жизни. М.: Госполитиздат, 1962. 48 с.

Гришин А. Заговор Тухачевского существовал // Комсомольская правда. 2017. 29 мая.

Громов А.В., Хорошавин В.А., Хумарьян С.Г. Самарский щит: Очерки, посвященные 90-летию Управления ФСБ по Самарской области. Самара, 2008. 320 с.

Дугин А.Н. Антисталинская подлость // Российские вести. 2013. 10-16 мая. № 12 (2119).

Дугин А.Н. Шифротелеграмма И. В. Сталина от 10 января 1939 года (источниковедческий анализ) // Вопросы истории. 2017. № 1. С. 97-112.

Зданович A.A. К вопросу изучения истории ВЧК-НКВД на современном этапе: полемические заметки // Клио (СПб.). № 3 (135). 2018. С. 196-205.

Зданович A.A. Польский крест советской контрразведки. Польская линия в работе ВЧКНКВД. 1918-1938. М.: Крафт+, 2017. 480 с.

Земсков В.Н. Сталин и народ. Почему не было восстания. М.: Алгоритм, 2014. 240 с.

Книга, обманувшая мир: сб. критических статей и материалов об «Архипелаге ГУЛАГ» А.И. Солженицына / сост. и ред. В.В. Есипов. М.: Летний сад, 2018.520 с.

Кондрашин В.В., Мозохин О.Б. Политотделы МТС в 1933-1934 гг. М.: Русская книга, 2017. 304 c.

Красильников С.А. Серп и Молох. М.: РОССПЭН, 2003.

Красильников С.А. Серп и Молох. М.: РОССПЭН, 2009.

Куренков Г.А. От конспирации к секретности: Защита партийно-государственной тайны в РКП(б) -ВКП(б), 1918-1941 гг. М.: АИРО XXI, 2015. 255 с.

Массовые репрессии в Алтайском крае 1937-1938 гг. Приказ № 00447 / сост. Г.Д. Жданова В.Н. Разгон, М. Юнге, Р. Биннер и др. М.: РОССПЭН, 2010. 751 с.

Мозохин О.Б. Право на репрессии: Внесудебные полномочия органов государственной безопасности (1918-1953). Жуковский; М.: Кучково поле, 2006. 480 с.

Мозохин О.Б. Статистические сведения о деятельности органов ВЧК-ОГПУ-НКВД-МГБ (1918-1953 гг.). М.: Алгоритм, 2016. 448 с.

Скоркин К. В. Обречены проиграть. Власть и оппозиция, 1922-1934. М.: ВивидАрт, 2011. $892 \mathrm{c}$.

Сталинизм в советской провинции: 1937-1938 гг. Массовая операция на основе приказа № 00447 / Под ред. М. Юнге, Б. Бонвеча, Р. Биннера. М.: РОССПЭН, 2009. 927 с.

Старков Б.А. «План Д»: вымыслы и действительность // Исторические чтения на Лубянке. 2005 год. М.: Кучково поле, 2006. С. 14-30.

Терещеенко А. Судьба генерала // ФСБ: За и против. 2013. № 2. С. 33.

ФСБ расставляет акценты // Российская газета. 2017. 20 дек. С. 4. 
Хлевнюк O.B. Сталинский период советской истории. Историографические тенденции и нерешенные проблемы // Уральский исторический вестник. 2017. № 3. С. 71-80.

Хлевнюк О.В. 1937-й: Сталин, НКВД и советское общество. М.: Республика, 1992. 270 с.

Чекисты на скамье подсудимых: сб. ст. / Сост. М. Юнге, Л. Виола, Дж. Россман. М.: Пробел-2000, 2017. 680 с.

«Через трупы врага на благо народа». «Кулацкая операция» в Украинской ССР: 19371941 гг.: в 2 т. М.: РОССПЭН, 2010. Т. 1. 711 с.

Через трупы врага на благо народа». «Кулацкая операция» в Украинской ССР: 19371941 гг.: в 2 т. М.: РОССПЭН, 2010. Т. 2. 711 с.

Эхо Большого террора. Сборник документов в трех томах. Под ред. Л. Виолы, Дж. Россмана, М. Юнге. Т. 1: Партийные собрания и оперативные совещания сотрудников Управлений НКВД УССР (ноябрь 1938 - ноябрь 1939 гг.). / сост.: В. Васильев, Л. Виола, Р. Подкур. М.: Пробел-2000, 2017. 736 с.

Эхо Большого террора. Сборник документов в трех томах. Под ред. Л. Виолы, Дж. Россмана, М. Юнге. Т. 2: Документы из архивных уголовных дел сотрудников органов УНКВД Украины, осужденных за нарушения социалистической законности (октябрь 1938 г. - июль 1943). Кн. 1: НКВД Молдавской АССР, Дорожно-транспортный отдел ГУГБ НКВД Северо-Донецкой железной дороги, УНКВД по Житомирской и УНКВД по Одесской области. / сост.: С. Кокин, Дж. Россман. М.: Пробел-2000, 2017. 720 с.

Эхо Большого террора. Сборник документов в трех томах. Под ред. Л. Виолы, Дж. Россмана, М. Юнге. Т. 3: Чекисты Сталина в тисках «социалистической законности». Эгодокументы 1938-1941 гг. / сост.: А. Савин, А. Тепляков, М. Юнге. М.: Пробел-2000, 2018. $928 \mathrm{c}$.

Юнге М., Биннер Р. Как террор стал «Большим». Секретный приказ № 00447 и технология его исполнения. М., АИРО-ХХ1, 2003. 352 с.

Юнге М., Бонвеч Б. Большевистский порядок в Грузии: в 2-х т. М.: АИРО-XXI, 2015. 640, $656 \mathrm{c}$.

Юнге М., Бордюгов Г., Биннер Р. Вертикаль Большого террора. История операции по приказу НКВД № 00447. М.: Новый хронограф, АИРО-ХХІ, 2008. 784 с.

\section{References}

"Cherez trupy vraga na blago naroda". "Kulackaya operaciya" v Ukrainskoj SSR: 19371941 gg.: v 2 t. ["Through the corpses of the enemy for the benefit of the people." "Kulak operation" in the Ukrainian SSR: 1937-1941]. M.: ROSSPEHN, 2010. T. 1. 743 s.

"Cherez trupy vraga na blago naroda". "Kulackaya operaciya" v Ukrainskoj SSR: 19371941 gg.: v 2 t. ["Through the corpses of the enemy for the benefit of the people." "Kulak operation" in the Ukrainian SSR: 1937-1941]. M.: ROSSPEHN, 2010. T. 2. $711 \mathrm{s.}$

Bagdasaryan V.EH. "Zagadochnyj tridcat' sed'moj". Opyt istoriograficheskogo modelirovaniya ["Mysterious thirty-seventh". Experience in historiographical modeling] // Istoriografiya stalinizma / pod red. N. A. Simoniya. M.: ROSSPEHN, 2007. S. 172-206.

Bagdasaryan V.EH. Tridcat' sed'moj - cherez prizmu istoriograficheskogo modelirovaniya [Thirty-seventh - through the prism of historiographical modeling] // Russkij sbornik. Issledovaniya po istorii Rossii". T. XXV / Red.-sost. O. R. Ajrapetov, M. A. Kolerov, B. Menning, A.YU. Polunov, P. CHejsti. M.: Modest Kolerov. 2018. S. 344-377.

Bakulin V.I. Kadrovye "chistki" 1933-1938 gg. v Kirovskoj oblasti i problemy konsolidacii sovetskogo obshchestva [Personnel "cleansing" of 1933-1938 in the Kirov region and the problems of consolidation of Soviet society]. // Otechestvennaya istoriya. 2006. № 1. S. 148-153.

Barsenkov A.S., Vdovin A.I. Istoriya Rossii. 1917-2009: ucheb. posobie dlya vuzov [Russian history. 1917-2009: textbook for universities]. 3-e izd. M.: Aspekt Press, 2010. 846 s.

Chekisty na skam'e podsudimyh: sb. st. [Security officers in the dock]./ Sost. M. Junge, L. Viola, Dzh. Rossman. M.: Probel-2000, 2017. 680 s. 
Dugin A.N. Antistalinskaya podlost' [Anti-stalinist meanness] // Rossijskie vesti. 2013. 10-16 maya. № 12 (2119).

Dugin A.N. SHifrotelegramma I.V. Stalina ot 10 yanvarya 1939 goda (istochnikovedcheskij analiz) [Stalin's encrypted telegram of January 10, 1939 (source study analysis)].// Voprosy istorii. 2017. № 1. S. 97-112.

Ehkho Bol'shogo terrora. Sbornik dokumentov v trekh tomah [Echo of the Great Terror. Collection of documents in three volumes]. Pod red. L. Violy, Dzh. Rossmana, M. Junge. T. 1: Partijnye sobraniya i operativnye soveshchaniya sotrudnikov Upravlenij NKVD USSR (noyabr' 1938 - noyabr' 1939 gg.). [Party meetings and operational meetings of the employees of the NKVD Ukrainian SSR Administrations (November 1938 - November 1939)]. / Sost.: V. Vasil'ev, L. Viola, R. Podkur. M.: Probel-2000, 2017. 736 s.

Ehkho Bol'shogo terrora. Sbornik dokumentov $\mathrm{v}$ trekh tomah. [Echo of the Great Terror. Collection of documents in three volumes].Pod red. L. Violy, Dzh. Rossmana, M. Junge. T. 2: Dokumenty iz arhivnyh ugolovnyh del sotrudnikov organov UNKVD Ukrainy, osuzhdennyh za narusheniya socialisticheskoj zakonnosti (oktyabr' 1938 g. - iyul' 1943). Kn. 1: NKVD Moldavskoj ASSR, Dorozhno-transportnyj otdel GUGB NKVD Severo-Doneckoj zheleznoj dorogi, UNKVD po ZHitomirskoj i UNKVD po Odesskoj oblasti [Documents from the archived criminal cases of employees of the Ukrainian People's Commissariat of Internal Affairs convicted for violations of socialist legality (October 1938 - July 1943). Prince 1: NKVD of the Moldavian Autonomous Soviet Socialist Republic, Road and Transport Division of the Main Directorate of State Security of the NKVD of the North-Donetsk Railway, NKVD in Zhytomyr and UNKVD in the Odessa region]./ Sost.: S. Kokin, Dzh. Rossman. M.: Probel-2000, 2017. 720 s.

Ehkho Bol'shogo terrora. Sbornik dokumentov $\mathrm{v}$ trekh tomah. [Echo of the Great Terror. Collection of documents in three volumes].Pod red. L. Violy, Dzh. Rossmana, M. Yunge. T. 3: Chekisty Stalina v tiskah "socialisticheskoj zakonnosti". Ehgo-dokumenty 1938-1941 gg. [Chekists Stalin in the grip of "socialist legality." Ego documents of 1938-1941]./ Sost.: A. Savin, A. Teplyakov, M. Junge. M.: Probel-2000, 2018. 928 s.

FSB rasstavlyaet akcenty [FSB puts accents] // Rossijskaya gazeta. 2017. 20 dek. S. 4.

Grishin A. Zagovor Tuhachevskogo sushchestvoval [Tukhachevsky conspiracy existed] // Komsomol'skaya pravda. 2017. 29 maya.

Gromov A.V., Horoshavin V.A., Humar'yan S.G. Samarskij shchit: Ocherki, posvyashchennye 90-letiyu Upravleniya FSB po Samarskoj oblasti [Samara Shield: Essays on the 90th anniversary of the FSB Administration in the Samara Region]. Samara, 2008. $320 \mathrm{~s}$.

Hlevnyuk O.V. 1937-j: Stalin, NKVD i sovetskoe obshchestvo[1937: Stalin, the NKVD and the Soviet society]. M.: Respublika, 1992. $270 \mathrm{~s}$.

Hlevnyuk O.V. Stalinskij period sovetskoj istorii. Istoriograficheskie tendencii i nereshennye problemy [The Stalin period of Soviet history. Historiographical trends and unresolved issues] // Ural'skij istoricheskij vestnik. 2017. № 3. S. 71-80.

Junge M., Binner R. Kak terror stal "Bol'shim". Sekretnyj prikaz № 00447 i tekhnologiya ego ispolneniya [How terror became "Big." Secret order number 00447 and the technology of its execution]. M., AIRO-XX1, 2003. 352 s.

Junge M., Bordyugov G., Binner R. Vertikal' Bol'shogo terrora. Istoriya operacii po prikazu NKVD № 00447 [Vertical Grand Terror. The history of the operation on the orders of the NKVD number 00447]. M.: Novyj hronograf, AIRO-XXI, 2008. $784 \mathrm{s.}$

Kniga, obmanuvshaya mir: sb. kriticheskih statej i materialov ob "Arhipelage GULAG" A.I. Solzhenicyna [A book that deceived the world: a collection of critical articles and materials about the "GULAG Archipelago" by A. I. Solzhenitsyn]. / sost. i red. V.V. Esipov. M.: Letnij sad, 2018. $520 \mathrm{~s}$.

Kondrashin V.V., Mozohin O.B. Politotdely MTS v 1933-1934 gg. [MTS political departments in 1933-1934]. M.: Russkaya kniga, 2017. $304 \mathrm{~s}$.

Krasil'nikov S.A. Serp i Moloh. [Sickle and Moloch].M.: ROSSPEHN, 2003.

Krasil'nikov S.A. Serp i Moloh. [Sickle and Moloch].M.: ROSSPEHN, 2009. 
Kurenkov G.A. Ot konspiracii k sekretnosti: Zashchita partijno-gosudarstvennoj tajny v RKP(b)VKP(b), 1918-1941 gg. [From conspiracy to secrecy: Protecting party-state secrets in the RCP (b)VCP (b), 1918-1941]. M.: AIRO XXI, 2015. 255 s.

Massovye repressii v Altajskom krae 1937-1938 gg. Prikaz № 00447 [Mass repressions in the Altai Territory of 1937-1938 Order № 00447]. / sost. G. D. ZHdanova, V. N. Razgon, M. Junge, R. Binner i dr. M.: ROSSPEHN, 2010. $751 \mathrm{~s}$.

Mozohin O.B. Pravo na repressii: Vnesudebnye polnomochiya organov gosudarstvennoj bezopasnosti (1918-1953). [The right to repression: The extraordinary jurisdiction of state security agencies (1918-1953)]. Zhukovskij; M.: Kuchkovo pole, 2006. 480 s.

Mozohin O.B. Statisticheskie svedeniya o deyatel'nosti organov VCHK-OGPU-NKVD-MGB (1918-1953 gg.). [Statistical information on the activities of the bodies of the Cheka-OGPUNKVD-MGB (1918-1953)]. M.: Algoritm, 2016. 448 s.

Skorkin K.V. Obrecheny proigrat'. Vlast' i oppoziciya, 1922-1934. [Doomed to lose. Power and opposition, 1922-1934]. M.: VividArt, 2011. $892 \mathrm{s.}$

Stalinizm v sovetskoj provincii: 1937-1938 gg. Massovaya operaciya na osnove prikaza № 00447 [Stalinism in the Soviet provinces: 1937-1938. Mass operation based on order No 00447] / pod red. M. Junge, B. Bonvecha, R. Binnera. M.: ROSSPEHN, 2009. 927 s.

Starkov B.A. "Plan D": vymysly i dejstvitel'nost' ["Plan D": fiction and reality] // Istoricheskie chteniya na Lubyanke. 2005 god. M.: Kuchkovo pole, 2006. S. 14-30.

Tereshchenko A. Sud'ba generala [The fate of the general].// FSB: Za i protiv. 2013. № 2. S. 33.

Verhovcev I. Leninskie normy partijnoj zhizni [Lenin norms of party life]. M.: Gospolitizdat, 1962. $48 \mathrm{~s}$.

Junge M., Bonvech B. Bol'shevistskij poryadok v Gruzii: v 2-h t. [Bolshevik order in Georgia]. M.: AIRO-XXI, 2015. 640, $656 \mathrm{~s}$.

Zdanovich A.A. $\mathrm{K}$ voprosu izucheniya istorii VCHK-NKVD na sovremennom ehtape: polemicheskie zametki [To the question of studying the history of the Cheka-NKVD at the present stage: polemical notes] // Klio (SPb.). № 3 (135). 2018. S. 196-205.

Zdanovich A.A. Pol'skij krest sovetskoj kontrrazvedki. Pol'skaya liniya v rabote VCHK-NKVD. 1918-1938. [Polish cross of the Soviet counterintelligence. Polish line in the Cheka-NKVD. 19181938]. M.: Kraft+, 2017. 480 s.

Zemskov V.N. Stalin i narod. Pochemu ne bylo vosstaniya [Stalin and the people. Why there was no rebellion]. M.: Algoritm, 2014. $240 \mathrm{~s}$.

Статья поступила в редакциию 28.02.2019 г. 